Article

\title{
Experimental Sensing and DFT Mechanism of Zn(II) Complex for Highly Sensitive and Selective Detection of Acetone
}

\author{
Mohd. Muddassir ${ }^{1, *}$, Mohammad Usman ${ }^{2}$, Abdullah Alarifi ${ }^{1}$, Mohd. Afzal ${ }^{1}$, \\ Khulud Abdullah Alshali ${ }^{1}$, Abeer Beagan ${ }^{1}{ }^{\mathbb{D}}$, Abhinav Kumar ${ }^{3}$, Naaser A. Y. Abduhd ${ }^{1}$ and \\ Musheer Ahmad 4,* \\ 1 Department of Chemistry, College of Science, King Saud University, Riyadh 11451, Saudi Arabia; \\ arifi@ksu.edu.sa (A.A.); Afzalanalytical@gmail.com (M.A.); 437202938@student.ksu.edu.sa (K.A.A.); \\ abeagan@ksu.edu.sa (A.B.); 439106262@ksu.edu.sa (N.A.Y.A.) \\ 2 Department of Chemistry, IIT Kanpur, Uttar Pradesh 208016, India; mohammadusman148@gmail.com \\ 3 Department of Chemistry, Faculty of Science, University of Lucknow, Lucknow 226 007, India; \\ abhinavmarshal@gmail.com \\ 4 Department of Applied Chemistry, Aligarh Muslim University, Aligarh 202002, India \\ * Correspondence: mmohammadarshad@ksu.edu.sa (M.M.); amusheer4@gmail.com (M.A.)
}

Received: 4 March 2020; Accepted: 15 April 2020; Published: 20 April 2020

\begin{abstract}
In the present work, a new $\mathrm{Zn}(\mathrm{II})$ perchlorate complex with 2,2'-bipyridyl of formulation $\left.\left\{[\mathrm{Zn} \text { (bipy) })_{2}\left(\mathrm{H}_{2} \mathrm{O}\right)\right]\left(\mathrm{ClO}_{4}\right)_{2}\right\}(\mathbf{1})$ was obtained and well analyzed. This chemosensor was evaluated as a selective sensor for acetone among the several different organic solvents $\left(\mathrm{CH}_{3} \mathrm{OH}, \mathrm{EtOH}, \mathrm{i}-\mathrm{PrOH}\right.$, i- $\left.\mathrm{BuOH}, \mathrm{CHCl}_{3}, \mathrm{CH}_{2} \mathrm{Cl}_{2}, \mathrm{CCl}_{4}, \mathrm{C}_{6} \mathrm{H}_{6}, \mathrm{C}_{7} \mathrm{H}_{8}, \mathrm{C}_{8} \mathrm{H}_{10}, \mathrm{C}_{2} \mathrm{H}_{3} \mathrm{~N}, \mathrm{C}_{3} \mathrm{H}_{7} \mathrm{NO}, \mathrm{C}_{4} \mathrm{H}_{8} \mathrm{O}_{2}, \mathrm{C}_{3} \mathrm{H}_{6} \mathrm{O}_{3}\right)$ in a fluorescence turn-off response in accordance with theoretical calculations. Sensing experiments were performed at ambient temperature which shows the acetone molecule distinctly reduces transfer of energy barrier to complex $\mathbf{1}$ and hence, produces remarkable luminescent quenching. Also, the weak intermolecular hydrogen-bonding interactions thanks to the presence of various hydrogen bonding donors and acceptors, exist between ligand molecules, which were broken during fluorescence, resulting in quenching. The stoichiometry ratio and association constant were evaluated using Benesi-Hildebrand relation giving 1:1 stoichiometry between complex $\mathbf{1}$ and acetone. Additionally, DFT results can also explicate the significant response on complex $\mathbf{1}$ upon addition of acetone. This work is vital in a new loom for the detection of acetone and other ketones.
\end{abstract}

Keywords: X-ray crystallography; H-bonding; Acetone; Fluorescence Sensing; DFT

\section{Introduction}

Acetone is a toxic reagent found extensively in nature, and acetone poisoning can occur through various external modes, such as inhalation, ingestion or direct body contact to living creatures because of its easy volatilization and toxicity. It is mostly harmful to the central nervous system's overall health. Similarly, this harmful chemical affects both cardiovascular and digestive health. Acetone is also highly toxic to the respiratory tract and the urinary system [1]. Acetone is predicted to stay mainly in the environmental compartment to which it is released. This is true when acetone is released into water (more than $99 \%$ is predicted to remain in water). As a result, it is of vital consequence to plan a novel sensor to detect acetone at a ppm level which is extremely beneficial not only for environment safety but also for the safety of human beings [2]. Supramolecular interactions play a critical task in the structural role of many molecules. It is well established that the important purposes of coordination complexes in comprising supramolecular interactions have become a wide area of 
field $[3,4]$, as it is effortless to preparation, easy process, cheap materials, simple availability and can be used as a sensors for useful applications. In this context, the heterocyclic bipyridyl ligands have been much studied because of the facts that the electron donating ability from its nitrogen atoms. Furthermore, the donation of electron and ability of nitrogen to coordinate further create the environment in biological systems [5-7]. Literature report supports that the complexes isolated from bipyridine ligand exhibit interesting photophysical behaviors and widely applicable [8-10]. Several other properties like short response time, high sensitivity, ease of detection, and cost-effectiveness, make the luminescent complexes potential for the use in fluorescence sensing. These molecules can be applicable to detect organic volatile solvent and explosive materials for example, trinitrotoluene and dinitrotoluene [11-18]. Hence, it is of much importance to explore the the nature and dynamics of bipyridyl ligands and the metal complexes obtain from this ligand. Late transition metal ions (e.g., $\mathrm{d}^{10}$ systems) coordinated to entities capable of supramolecular interactions, such as $\mathrm{N}$ - or O-based ligands, can fluoresce remarkably [16-20]. In the recent past, luminescent properties of $\mathrm{Zn}$ (II) coordination complexes of 2,2'-bipyridyl (bpy) has been studied which possesses essential properties both in the solid state [21,22] and in solution [23,24].

Most importantly, it has a $\pi$ conjugated system that can be utilized for photoluminescence. It is well-known that $\mathrm{Zn}^{2+}, \mathrm{Cd}^{2+}$, and $\mathrm{Ln}^{3+}$ are usually adopted as luminescent cations, and we shall exploit these in our future work. An additional advantage of using $\mathrm{Zn}$ (II) $\mathrm{d}^{10}$ system in fluorescence sensing is their selectivity toward certain solvents such as acetone [17]. The detection of different solvents has received great attention because of the increasing solvent toxicity and wastewater, which are relevant for environmental and industrial monitoring, human health, food safety, etc. Sun et al. have pleasingly explained the selective nature of $\mathrm{d}^{10}$ systems and $\pi$ conjugated ligands in their experimental investigation [14-16,19].

Due to simplicity, and its easy reaction process, planar ligand and its mononuclear $\mathrm{Zn}$ (II) complexes are considered as an excellent choice for fluorescence sensing [25]. Recently, Hui Li et al. have demonstrated that molecular Zn(II) with salphen-based Schiff base complexes exhibited remarkable abilities of fluorescent recognition to iodide anions in tetrahydrofuran (THF) [26]. Similarly, Michael J. Knapp's group have shown that monometallic $\mathrm{Zn}$ (II) complex is quenched extraordinarily in solution by nitroaromatics and 2,3-dimethyl-2,3-dinitrobutane (DMNB), which is a chemical signature of explosives [27], which proves that Zn(II)-complex-based materials can not only sense harmful solvents but also can detect explosive materials.

Considering these, we have synthesized $\mathrm{Zn}(\mathrm{II})$ complex $\left\{\left[\mathrm{Zn}(\text { bipy })_{2}\left(\mathrm{H}_{2} \mathrm{O}\right)\right]\left(\mathrm{ClO}_{4}\right)_{2}\right\}(\mathbf{1})$ and characterized by single $X$-ray crystallography, NMR spectroscopy, TGA, IR spectroscopy, elemental analysis, UV-Vis spectroscopy, and fluorescence spectroscopy. From the experimental and theoretical investigation, we conclude that the complex $\mathbf{1}$ could selectively detect the acetone without the requirement of any additional processes such as preactivation, heating, or $\mathrm{pH}$ variation and, hence can be utilized as chemosensor for acetone and other ketones family.The results could be relevant not only to the $\mathrm{Zn}(\mathrm{II}) \mathrm{d}^{10}$ system but also to related systems involving bpy-like ligands, e.g., pyridyl-imidazole derivatives, imidazolinones, etc.

\section{Material and Methods}

\subsection{Materials}

$\mathrm{ZnClO}_{4} \cdot 6 \mathrm{H}_{2} \mathrm{O}$ (Fluka), 2,2'-bipyridine (Alfa Aesar) was used as received. All solvents, such as methanol, ethanol, isopropanol, isobutanol, chloroform, dichloromethane, carbon tetrachloride, benzene, toluene, ethylbenzene, acetonitrile, dimethyformamide, ethyl acetate, dimethyl carbonate, acetone, cyclohexanone, 4-heptanone and 5-nonanone (Sigma-Aldrich) were utilized as received. 


\subsection{Methods and Instrumentation}

Microanalysis (CHN) was carried out with a Carlo Erba Analyzer Model 1108. Molar conductance was measured at room temperature on a Digsun electronic conductivity bridge. An FTIR spectrometer (Interspec 2020) was used for recording the IR spectra of samples in KBr pellets in the range $4000-400 \mathrm{~cm}^{-1}$. Electronic spectra were recorded on UV-1700 PharmaSpec UV-Vis spectrophotometer (Shimadzu). Emission spectra were recorded on a Shimadzu RF-6000 fluorescence spectrophotometer. TGA was performed on a Universal V3.8 B TA SDT Q600 Build 51 thermal analyzer under a nitrogen atmosphere using alumina powder as the reference material. ${ }^{1} \mathrm{H}$ and ${ }^{13} \mathrm{C}$ NMR spectra were recorded at $25^{\circ} \mathrm{C}$ on a JEOL $400 \mathrm{NMR}$ spectrometer.

\subsection{Crystal Structure Determination}

Detailed crystal structure measurement has been given in full in the Supplementary Material.

\subsection{Synthesis}

The complex $\left\{\left[\mathrm{Zn}(\text { bipy })_{2}\left(\mathrm{H}_{2} \mathrm{O}\right)\right]\left(\mathrm{ClO}_{4}\right)_{2}\right\}(\mathbf{1})$ was obtained by dissolving $2 \mathrm{mmol}$ of 2,2'-bpy $(0.312 \mathrm{~g})$ and $1 \mathrm{mmol} \mathrm{ZnClO}_{4} \cdot 6 \mathrm{H}_{2} \mathrm{O}(0.372 \mathrm{~g})$ in $30 \mathrm{~mL}$ ethanol. The solution was stirred at room temperature. A colorless precipitate appeared after ca. $6 \mathrm{~h}$, which was re-dissolved in water/acetonitrile (20:80) mixture and kept for crystal growth. After seven days, colorless, needle-shaped crystals were obtained, which were washed with hexane and stored for further analysis. Yield, $60 \%$; m.p., $265^{\circ} \mathrm{C}$. Anal. Calc. for $\mathrm{C}_{20} \mathrm{H}_{18} \mathrm{Cl}_{2} \mathrm{~N}_{4} \mathrm{O}_{9} \mathrm{Zn}(\%) \mathrm{C}, 40.39 ; \mathrm{H}, 3.05 ; \mathrm{N}, 9.42$, Found: $\mathrm{C}, 41.48 ; \mathrm{H}, 2.99 ; \mathrm{N}, 9.35$. Conductivity $\left(1 \times 10^{-3} \mathrm{M}, \mathrm{DMSO}\right): 210.0 \Omega^{-1} \mathrm{~cm}^{2} \mathrm{~mol}^{-1}$ (1:2 electrolyte). IR $\left(\mathrm{KBr}, \mathrm{cm}^{-1}\right): 3481\left(\mathrm{OH}, \mathrm{H}_{2} \mathrm{O}\right) ; 3101(\mathrm{CH}$, aromatic); $1442\left(\mathrm{CH}\right.$, aromatic); 1601, 1576, 1493 (bipyridyl N); $1100\left(\mathrm{ClO}_{4}\right) ; 413(\mathrm{Zn}-\mathrm{O}) ; 415(\mathrm{Zn}-\mathrm{N})$. UV-vis (DMSO, nm): 209, 295.

\section{Results and Discussion}

\subsection{Synthesis and Characterization}

The product $\left\{\left[\mathrm{Zn}(\text { bipy })_{2}\left(\mathrm{H}_{2} \mathrm{O}\right)\right]\left(\mathrm{ClO}_{4}\right)_{2}\right\}(\mathbf{1})$ was characterized using single $\mathrm{X}$-ray crystallography, NMR, TGA, IR, elemental analysis, and UV-Vis spectroscopy (Supplementary Material, Scheme S1). The complex is stable toward air and moisture.

\subsection{X-ray Structure}

The ORTEP structure of complex $\mathbf{1}$ is shown in Supplementary Material, Figure S1. This complex crystallizes in the monoclinic space group P21/n $(Z=4)$ with a pentacoordinated $\mathrm{Zn}(\mathrm{II})$ center. The crucial parameters of the Zn complex are listed in Supplementary Material, Table S1.

Complex 1 adopts a square pyramidal geometry by coordinating through the $\mathrm{N}$ atoms of the two bipyridyl molecules and $\mathrm{O}$ atom of one water molecule. Two uncoordinated perchlorate anions present in the lattice complete the charge balance and are extensively involved in hydrogen bonding. The unit cell of complex 1 shows the coordination of the four $\mathrm{Zn}(\mathrm{II})$ ions with the uncoordinated perchlorate anions (Figure 1). 


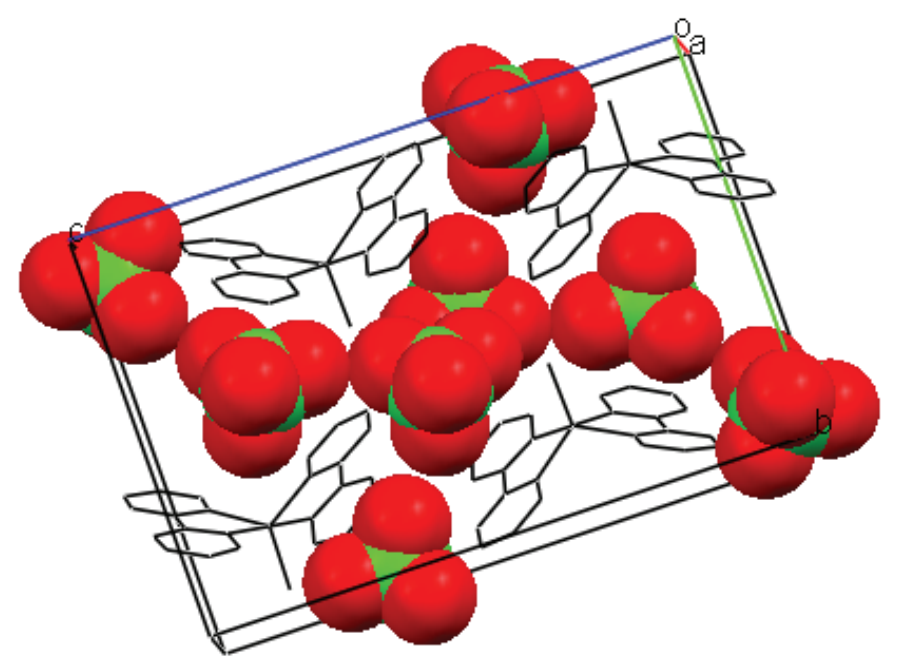

Figure 1. Cell of complex $\left\{\left[\mathrm{Zn}(\text { bipy })_{2}\left(\mathrm{H}_{2} \mathrm{O}\right)\right]\left(\mathrm{ClO}_{4}\right)_{2}\right\}(\mathbf{1})$.

Figure 2 shows the space-filling model of complex 1 . The $\mathrm{Zn}-\mathrm{N}$ bond distances are in the range 2.061 (3)-2.104 (3) $\AA$, while the Zn-O bond distance is $2.028 \AA$ (Supplementary Materials, Table S2). All the bond angles are in the range $79.03(13)-178.83(13)\left({ }^{\circ}\right)$.

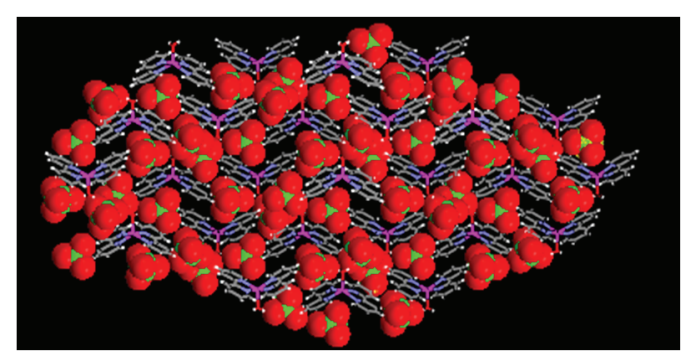

Figure 2. Model of complex $\left\{\left[\mathrm{Zn}(\text { bipy })_{2}\left(\mathrm{H}_{2} \mathrm{O}\right)\right]\left(\mathrm{ClO}_{4}\right)_{2}\right\}(\mathbf{1})$.

All the bond lengths and bond angles of the synthesized complex are almost the same as that of similar coordination complexes [28]. The complex exhibits hydrogen bonding between the bonded water molecule and non-bonded perchlorate anions. The oxygen atoms $(\mathrm{O} 2, \mathrm{O} 3, \mathrm{O} 4)$ of one of the perchlorate anions are involved in $\mathrm{C}-\mathrm{H} \cdots \cdots . \mathrm{O}$ intermolecular interactions with the $\mathrm{H}$ atoms of the bonded bipyridyl molecule in the range 2.525(13)-2.966(27) $\AA$. O atoms (O7, O8, O9) of another perchlorate anion are involved in $\mathrm{C}-\mathrm{H} \cdots \cdots . \mathrm{O}$ intermolecular interactions with the $\mathrm{H}$ atoms of the coordinated bipyridyl molecule, in the range 2.477(11)-3.004(28) $\AA$.

\subsection{NMR Spectral Studies}

The chemical shifts were identified by their intensity and multiplicity patterns. The total number of protons as calculated from the integration curves was in agreement with the expected molecular composition of the compound. The complexation between the metal cation and the complex decreased the electron density at the $\mathrm{N}$ atoms, weakening the shielding effect on the neighboring protons and causing a downfield shift of the signal. The ${ }^{1} \mathrm{H}$ NMR spectrum of complex1in DMSO- $\mathrm{d}_{6}$ displays several interesting features in comparison to the free bipyridyl ligand (Supplementary Materials, Figure S2). Complex 1 exhibited a merged and intense peak at $3.42 \mathrm{ppm}$ compared to the distinct signal of coordinated $\mathrm{H}_{2} \mathrm{O}$, due to overlapping and fast $\mathrm{O}-\mathrm{H}$ exchange with coordinated water molecule and residual water content of $\mathrm{DMSO}^{-\mathrm{d}_{6}}$ [29]. Signals due to aromatic protons appeared in the range $7.8-8.7 \mathrm{ppm}$, while the signals at $1.0 \mathrm{ppm}$ correspond to trace amounts of lattice ethanol. In the ${ }^{13} \mathrm{C}$ 
NMR spectrum, signals from aromatic carbon appeared at 123-149 ppm (Supplementary Materials, Figure S3).

\subsection{Thermal Studies}

Thermogravimetric analysis of complex 1 was carried out from 25 to $800^{\circ} \mathrm{C}$ to study its pyrolysis pattern. The thermogram of the complex 1 (Supplementary Materials, Figure S4) suggests that weight loss occurs in five steps over the temperature range 75-160, 210-350, 320-360, 365-600 and $610-800{ }^{\circ} \mathrm{C}$. These were in close agreement with the proposed structure. The weight loss in the temperature range $75-160{ }^{\circ} \mathrm{C}$ confirmed the removal of traces of ethanol while that in the range $210-350{ }^{\circ} \mathrm{C}$ corresponded to the removal of coordinated water molecules $[30,31]$. This conclusion was based on the fact that the water molecules are extensively hydrogen bonded with the neighboring perchlorate anions, and, hence, required more heat compared with the lattice water molecules. The weight loss in the range $320-360^{\circ} \mathrm{C}$ corresponded to the removal of both the perchlorate anions. At $365-600^{\circ} \mathrm{C}$, the compound exhibited $\sim 41 \%$ weight loss, corresponding to the decomposition of the bipyridyl group. Finally, the plateau from 710 to $850^{\circ} \mathrm{C}$ corresponded to the formation of zinc oxide as the final product.

\subsection{IR Spectroscopy}

The infrared spectrum of complex 1 (Supplementary Material, Figure S5) shows a band of the relatively weak peak at $3101 \mathrm{~cm}^{-1}$ owing to aromatic $-\mathrm{CH}$ stretching and a sharp, intense peak at $1442 \mathrm{~cm}^{-1}$ owing to aromatic $-\mathrm{CH}$ bending. Absorption bands at 1601, 1576, and $1493 \mathrm{~cm}^{-1}$ were consistent with the coordination of the $\mathrm{N}$ atom to the metal center [32]. The corresponding peaks were observed at slightly lower frequencies in the free bipyridyl ligand. Besides, a strong $-\mathrm{OH}$ band at $3481 \mathrm{~cm}^{-1}$ was also observed for complex 1, owing to the presence of coordinated water molecules [33]. The crystal structure of complex 1 suggests that there are no interactions between the metal center and the anions, although there is a weak hydrogen bond between one of the perchlorate oxygen atoms and the aqua group of the cation. The T2 mode near $1100 \mathrm{~cm}^{-1}$ appears as an intense band, characteristic of perchlorate anions. The several smaller bands observed between 600 and $700 \mathrm{~cm}^{-1}$ are indicative of significant interactions between the perchlorate group and the cation. The splitting observed in this region may arise because of various factors, and the region is generally less informative than the lower-energy region. This conclusion is borne out by the results obtained for the coordinated perchlorates.

The medium-intensity bands in the region $413-415 \mathrm{~cm}^{-1}$ corresponded to (Zn-O) and ( $\left.\mathrm{Zn}-\mathrm{N}\right)$ [34], thus providing additional evidence for the formation of complex 1.

\subsection{Electronic Spectra}

The UV spectrum of complex 1 exhibited bands at $209 \mathrm{~nm}$, which corresponded to the $\pi-\pi^{*}$ transitions due to the long-lived triplet excited state of the aromatic moiety. This band undergoes a hypsochromic shift concerning the free bipyridyl ligands. Additionally, ligand to metal charge transfer (LMCT) transitions for the complex were observed at around $295 \mathrm{~nm}$ (Supplementary Materials, Figure S6). No d-d electronic transitions were observed because of completely filled $d$-orbital [35].

\subsection{Fluorescence Sensing Property}

It is reported that the $\mathrm{d}^{10}$-based ions possessing a closed-shell electronic configuration with $\pi$-conjugated skeleton have a trivial impact on the excited state profile, while other metal ions with different electronic configurations quench the luminescence, especially in solvents such as acetone [16-20]. To explore the potential applications of our synthesized Zn-based coordination complex in probing small organic molecules, we examined the outcome of organic solvents on the fluorescence of the complex 1 .

The fluorescence of the complex $1\left(1.0 \times 10^{-5} \mathrm{M}\right)$ was studied in DMSO at room temperature. The complex 1 exhibited remarkable fluorescence, and intense emission bands were observed at $330 \mathrm{~nm}$ 
$\left(\lambda_{\mathrm{ex}}=295 \mathrm{~nm}\right)$. It is well known that the arrangement of certain structural features like rigidity of aromatic backbone of the ligands can enhance the intra/intermolecular interactions, thus favoring the energy transfer $[18,20]$. Generally, the enhancement in fluorescence intensity of metal complexes with $\pi$-conjugated ligands is much more as compared to free ligand, because the latter hampers the deformation of the ligand and provoke nonradiative relaxation [36].

The fluorescence sensing experiment with the synthesized complex 1 was performed in the presence of different organic solvents (Figure 3). The spectral response shows drastic decline in the emission intensity of complex 1 maximum at $325 \mathrm{~nm}$ in presence of acetone.

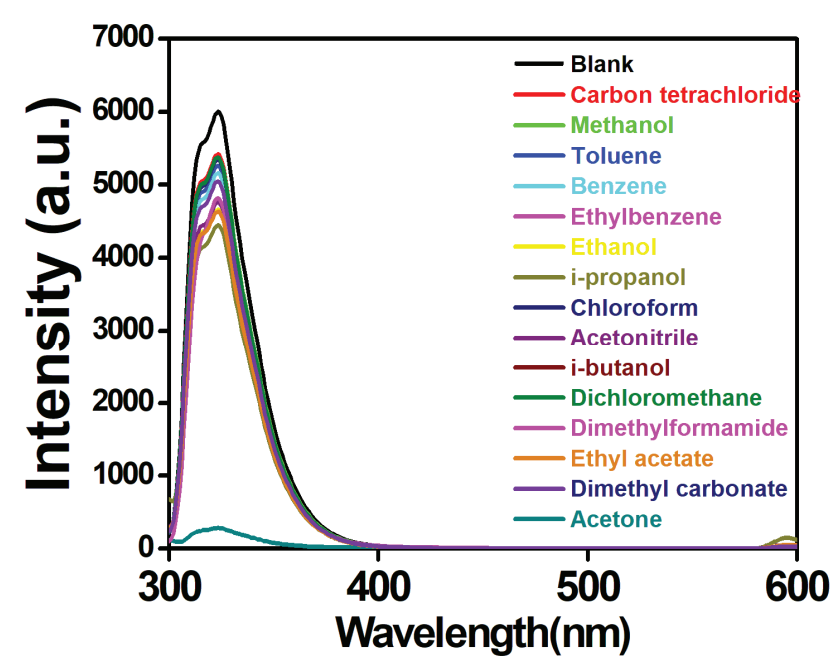

Figure 3. Fluorescence spectra of complex $\left\{\left[\mathrm{Zn}(\text { bipy })_{2}\left(\mathrm{H}_{2} \mathrm{O}\right)\right]\left(\mathrm{ClO}_{4}\right)_{2}\right\}$ (1)dissolved in DMSO (blank) and upon the addition of different organic solvents.

For a detailed examination of the sensitivity of the complex $\mathbf{1}$ for sensing acetone, the quenching efficiencies of the complex 1 with increasing amounts of acetone $(0-1.05 \mathrm{mM})$ was investigated which exhibits that the emission profile decreases sharply in presence of added amounts of acetone (Figure 4).

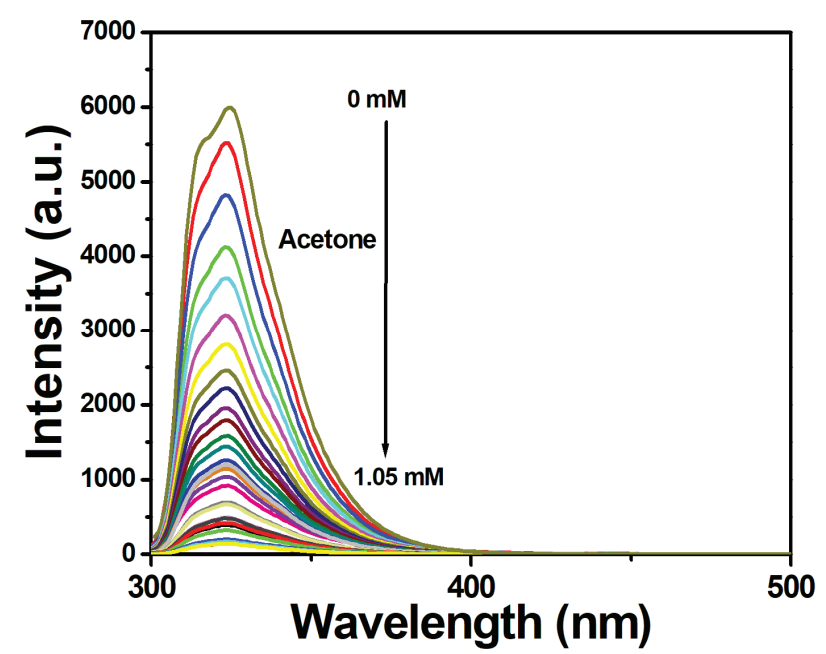

Figure 4. Changes in the fluorescence intensity of complex $\left\{\left[\mathrm{Zn}(\text { bipy })_{2}\left(\mathrm{H}_{2} \mathrm{O}\right)\right]\left(\mathrm{ClO}_{4}\right)_{2}\right\}(\mathbf{1})$ upon titration with different concentrations of acetone $(0-1.05 \mathrm{mM})$.

The value of the association constant gives an idea of the strength of binding between the complex and the added molecule. In order to have a quantitative estimate of the association of complex $1(10 \mu \mathrm{M})$ with the increasing concentration of acetone $(0-1.05 \mathrm{mM})$, we have exploited the fluorescence titration 
data to determine the association constant, using the modified Benesi-Hildebrand equation [37] as given below

$$
\frac{1}{\Delta \mathrm{F}}=\frac{1}{\Delta F_{\max }}+\frac{1}{K \Delta F_{\max }} \frac{1}{[L]}
$$

Where $\Delta \mathrm{F}=\mathrm{F}_{\mathrm{x}}-\mathrm{F}_{0}$ and $\Delta \mathrm{F}_{\max }=\mathrm{F}_{\infty}-\mathrm{F}_{0}$, where $\mathrm{F}_{0}, \mathrm{~F}_{\mathrm{x}}$ and $\mathrm{F}_{\infty}$ are the fluorescence intensities of complex $\mathbf{1}$ in the absence of acetone, at an intermediate acetone concentration, and at a concentration allowing complete interaction, respectively; $\mathrm{K}$ is the association constant and [L] is the acetone concentration. The double reciprocal plot of $1 / \Delta \mathrm{F}$ against $1 /[$ Acetone] gives a straight line (Figure 5 ). From this plot, we have confirmed 1:1 stoichiometry between complex $\mathbf{1}$ and acetone. The assessment constant $(\mathrm{K})$ is calculated from the ratio of the intercept to the slope of the linear plot in Figure 5 and the value of $\mathrm{K}$ was $1.5 \times 10^{3} \mathrm{M}^{-1}$. The high value of the association constant assumes that complex 1 had great potential for the detection of trace amount of acetone.

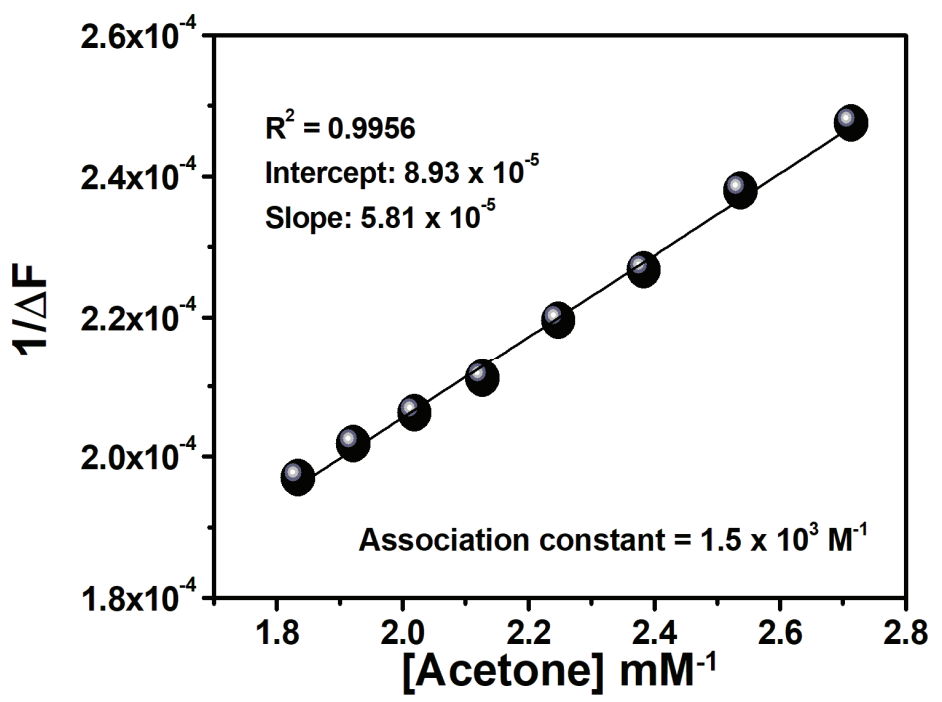

Figure 5. Double reciprocal plot for 1:1 association between complex $\left\{\left[\mathrm{Zn}(\text { bipy })_{2}\left(\mathrm{H}_{2} \mathrm{O}\right)\right]\left(\mathrm{ClO}_{4}\right)_{2}\right\}(\mathbf{1})$ and acetone.

The limit of detection was calculated from the increamental amount of added acetone based on a reported procedure [38]. To achieve the slope, the emission profile of complex $\mathbf{1}$ at $325 \mathrm{~nm}$ was plotted versus concentration of acetone (Supplementary Material, Figure S7) and the limit of detection was calculated with the help of following equation:

$$
\text { Detection limit }=3 \sigma / \mathrm{M}
$$

Where $\sigma$ is the standard deviation of blank measurement and $M$ is the slope between the fluorescence intensity and acetone concentration. The detection limit was found to be in order of $1.80 \times 10^{-5} \mathrm{M}$. Hence, complex 1 confirms the selective estimation for acetone was calculated to be $18 \mu \mathrm{M}$.

The addition of other solvents did not exhibit any remarkable quenching. These outcomes revealed that the complex 1 selectively detect the acetone. At the same time, the sensing ability of complex 1 towards the acetone was not affected by other organic solvents (Figure 6). It means that the complex 1 can effectively sense acetone even if the taster is impure with additional solvents. Besides, we did not preactivate our system by means of any other physical parameters like heating, $\mathrm{pH}$ maintenance, or any other external factor, which is in contrast to lanthanides and a few other coordination complexes that require preactivation [39-41]. 


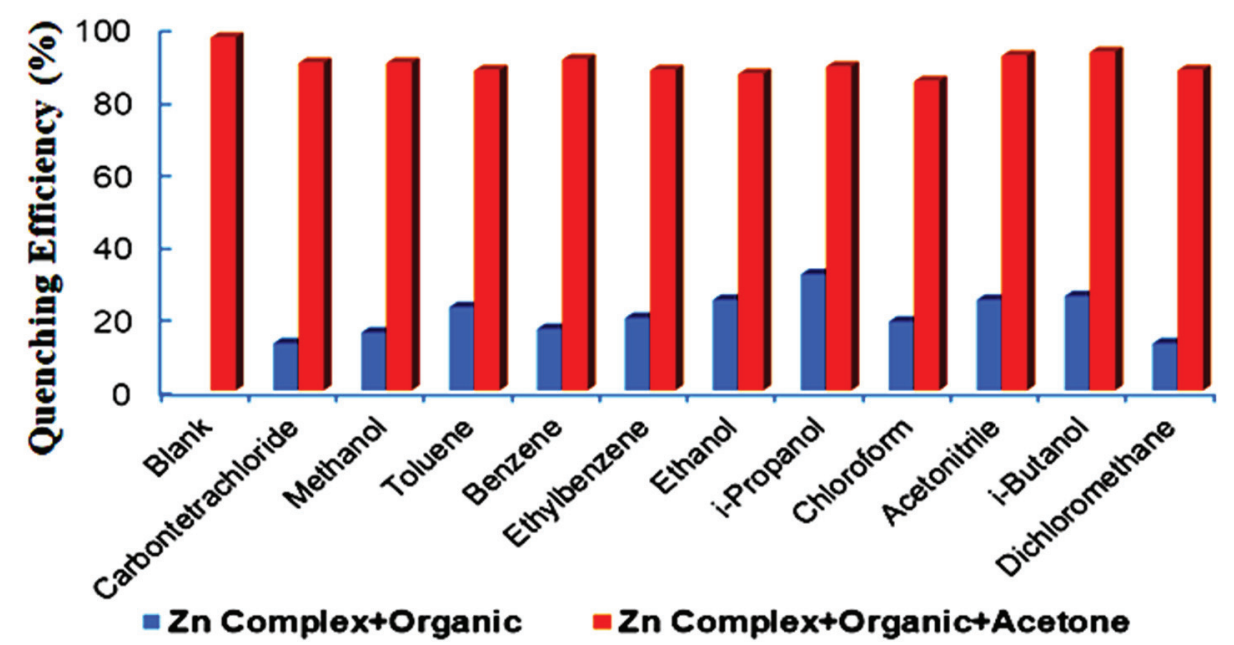

Figure 6. Quenching efficiency of complex $\left\{\left[\mathrm{Zn}(\text { bipy })_{2}\left(\mathrm{H}_{2} \mathrm{O}\right)\right]\left(\mathrm{ClO}_{4}\right)_{2}\right\}(\mathbf{1})$ upon the addition of different organic solvents, except for acetone (blue) and subsequent addition of acetone (red).

The quenching was nearly proportional to the acetone concentration, and complete quenching was observed upon the addition of $1.05 \mathrm{mM}$ of acetone. This demonstrates that complex 1 selectively senses even minimal amounts of acetone and, hence, may considered as a potential candidate for the selective sensing of acetone.

In order to explore whether the interaction between the $-\mathrm{C}=\mathrm{O}$ bond of acetone and the frameworks of complex 1 caused the fluorescence quenching, the fluorescence of various ketones was examined. Figure 7 demonstrates that ketones such as cyclohexanone, 4-heptanone, and 5-nonanone exhibited the highest quenching. This suggests that the fluorescence quenching may be caused by the interaction between the $-\mathrm{C}=\mathrm{O}$ bond of ketone and the frameworks of complex 1 .

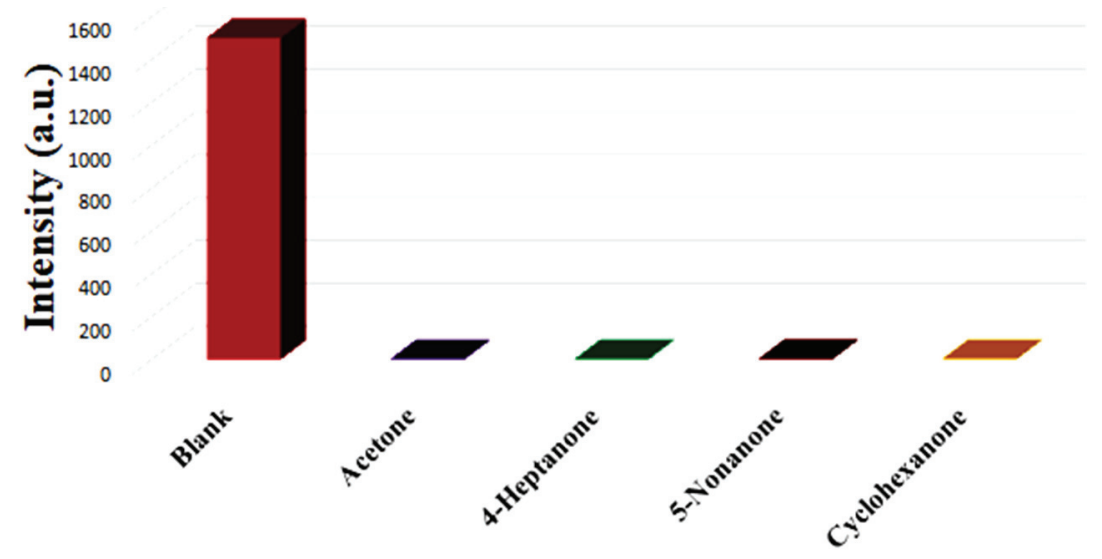

Figure 7. Fluorescence intensity of complex $\left\{\left[\mathrm{Zn}(\text { bipy })_{2}\left(\mathrm{H}_{2} \mathrm{O}\right)\right]\left(\mathrm{ClO}_{4}\right)_{2}\right\}(\mathbf{1})$ in various ketones upon excitation at $295 \mathrm{~nm}$.

The observed fluorescence-quenching effect may be attributed to the interactions between the $\mathrm{Zn}$ (II) metal ion framework of complex $\mathbf{1}$ and acetone, since $\mathrm{Zn}$ (II) is oxophilic in nature, and it might be possible that acetone may bond with the $\mathrm{Zn}$ (II) complex through supramolecular interaction. Upon excitation, an energy transfer from the ligands to the acetone molecules occurred and resulted in fluorescence quenching. It would be very interesting to determine further, regarding our theory, whether we get X-ray crystal structure from acetone-rich solution. This would show whether the ketone coordinates to $\mathrm{Zn}(\mathrm{II})$, but despite our efforts we could not get such a crystal. 


\subsection{DFT Studies}

To get a deeper insight into the mechanism of the fluorescence-quenching behaviors of complex 1 with acetone, a series of DFT calculations were carried out. Firstly, we have screened the energies of frontier molecular orbitals of all the solvents and complex 1 (Supplementary Material, Figure S8). From the analysis of the highest occupied molecule orbital (HOMO) and lowest occupied molecule orbital (LUMO) energies of solvents, it was found that the HOMO energy of acetone, benzene, toluene and ethyl benzene is greater than the HOMO energy of complex $\mathbf{1}$ alone. Addition of these solvents to complex 1 may restrict the $\pi-\pi^{*}$ intramolecular charge transfer (responsible for the fluorescence), occurring from one bipyridyl moiety to another, as HOMO and LUMO are mainly located on both of the bipyridyl moiety of complex 1 after the formation of either ground state or excited state charge-transfer $\mathrm{CT}$ adduct. However, our observed experimental results suggest that only acetone molecules restricted the intermolecular charge transfer of complex 1, because quenching is observed only in the case of acetone. Surprisingly, the HOMO energies of benzene, toluene and ethyl benzene are greater than acetone, yet fluorescence quenching is observed only in the presence of acetone (if HOMO energy is the only factor).

To find out the reason for this, we optimized complex $\mathbf{1}$ with each solvent used for sensing and analyzed their geometric parameters and frontier molecular orbital (FMO) distributions (Supplementary Material, Figure S9). The FMO analysis of adducts of complex $\mathbf{1}$ with solvent suggests that HOMO and LUMO separately located on only acetone and one bipyridyl moiety of complex $\mathbf{1}$, respectively, while in all other cases mixed distributions of FMOs were observed (Figure 8). Hence, in all other cases, especially in benzene, toluene and ethyl benzene, which form adducts of complex 1 , the intermolecular $\pi-\pi^{*}$ charge transfer is still not affected after adduct formation.

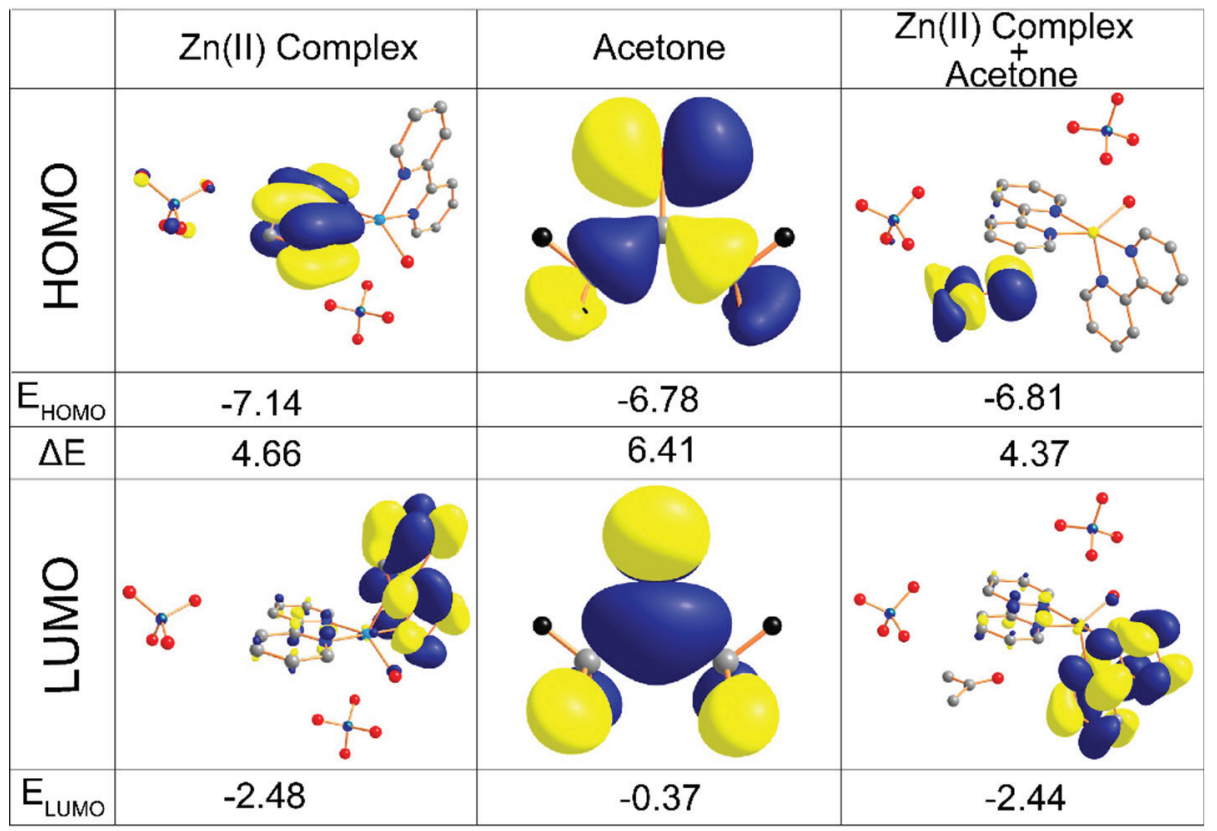

Figure 8. Comparative frontier molecular orbital diagram.

Furthermore, we have also carried out electron localization function (ELF) analysis to explore the nature of non-covalent forces which stabilize the acetone- $\mathrm{Zn}$ (II) complex $\mathbf{1}$ adduct. The ELF analysis suggested that the acetone- $\mathrm{Zn}$ (II) complex 1 stabilized through the lone pair $\cdots \pi$ interaction between the lone pair of the carbonyl group and the $\pi$ cloud of the bipyridyl moiety of complex 1 (Supplementary Material, Figure S10) while, in all other cases, distances and geometric orientation of other solvents and $\mathrm{Zn}$ (II) complex are not compatible to form any kind of non-covalent interaction (Supplementary Material, Figure S11). In short, the observed selective fluorescence-quenching effect in 
the presence of acetone can be attributed to the lone pair $\cdots \pi$ interactions between the bipyridyl moiety of the complex 1 framework and the carbonyl group of acetone, which form a stable acetone- $\mathrm{Zn}$ (II) adduct.

Upon excitation, electron transfer from the acetone molecule to the bipyridyl moiety of complex $\mathbf{1}$ occurred, due to which the intermolecular $\pi-\pi^{*}$ charge transfer between bipyridyl moieties is broken and fluorescence quenching occurs (Figure 9).

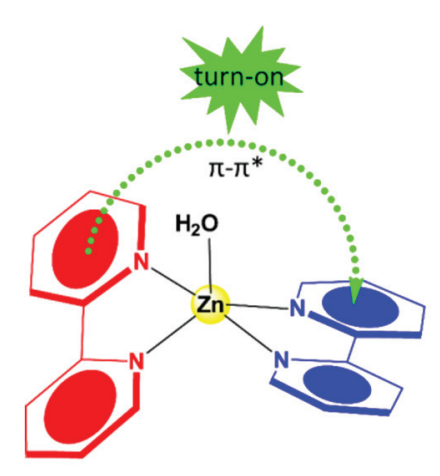

Fluorescence emission

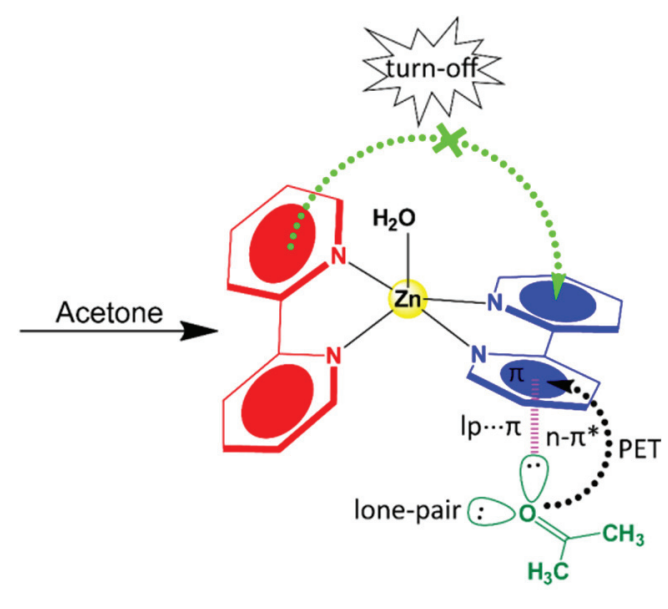

Fluorescence quenching

Figure 9. Schematic representation of the mechanism of the fluorescence quenching.

In brief, the acetone molecule distinctly reduces energy transfer to complex $\left\{\left[\mathrm{Zn}(\text { bipy })_{2}\left(\mathrm{H}_{2} \mathrm{O}\right)\right]\left(\mathrm{ClO}_{4}\right)_{2}\right\}(\mathbf{1})$, to produce remarkable luminescent quenching, which is absent in the rest of the solvent molecules. Additionally, weak intermolecular hydrogen-bonding interactions, thanks to the presence of various hydrogen bonding donors and acceptors, may also exist between bipyridyl moieties which were broken, resulting in quenching.

\section{Conclusions}

A new $\mathrm{Zn}(\mathrm{II})$ perchlorate complex with 2,2'-bipyridyl of formulation $\left\{\left[\mathrm{Zn}(\text { bipy })_{2}\left(\mathrm{H}_{2} \mathrm{O}\right)\right]\left(\mathrm{ClO}_{4}\right)_{2}\right\}$ (1) was prepared and characterized by single $X$-ray crystallography, NMR, TGA, IR, elemental analysis, and UV-Vis spectroscopy. Due to the presence of intermolecular interactions in the complex, as observed in the packing diagrams, these complexes participated in fluorescence sensing. Upon excitation, electron transfer from the acetone molecule to the bipyridyl moiety of $\mathrm{Zn}$ (II) complex occurs, due to which intermolecular $\pi-\pi^{*}$ charge transfer between bipyridyl moieties is broken and fluorescence quenching occurs. The high quenching efficiency and excellent selectivity of the complex for acetone and other ketones make it a potential functional material for the detection of ketones, which was further proved by DFT analysis. This study provides new physical insights into the rational design of coordination-complex-based functional materials. Future work in this direction will be crucial to elucidate the specific roles of $\mathrm{d}^{10}$-based complexes in sensing.

Supplementary Materials: The following are available online at http://www.mdpi.com/2073-4352/10/4/324/s1, Table S1. Crystallographic data of $\left\{\left[\mathrm{Zn}(\text { bipy })_{2}\left(\mathrm{H}_{2} \mathrm{O}\right)\right]\left(\mathrm{ClO}_{4}\right)_{2}\right\}(1)$; Table S2. Selected bond lengths $[\AA]$ and bond angles $\left[{ }^{\circ}\right]$ of $\left\{\left[\mathrm{Zn}(\text { bipy })_{2}\left(\mathrm{H}_{2} \mathrm{O}\right)\right]\left(\mathrm{ClO}_{4}\right)_{2}\right\}(\mathbf{1})$; Table S3. The origin of the transitions from IR, NMR, UV-Vis and TGA and its description. Scheme S1. Synthetic scheme of complex $\left\{\left[\mathrm{Zn}(\text { bipy })_{2}\left(\mathrm{H}_{2} \mathrm{O}\right)\right](\mathrm{ClO} 4)_{2}\right\}$ (1); Figure S1.Thermal ellipsoidal presentation of the molecular structure of complex $\left\{\left[\mathrm{Zn}(\text { bipy })_{2}\left(\mathrm{H}_{2} \mathrm{O}\right)\right]\left(\mathrm{ClO}_{4}\right)_{2}\right\}$ (1) with $30 \%$ probability factor; Figure S2. The ${ }^{1} \mathrm{H}$ NMR spectrum of complex $\left\{\left[\mathrm{Zn}(\text { bipy })_{2}\left(\mathrm{H}_{2} \mathrm{O}\right)\right]\left(\mathrm{ClO}_{4}\right)_{2}\right\}(\mathbf{1})$ in DMSO- $_{6}$ at room temperature; Figure S3. The ${ }^{13} \mathrm{C}$ NMR spectrum of complex $\left\{\left[\mathrm{Zn}(\text { bipy })_{2}\left(\mathrm{H}_{2} \mathrm{O}\right)\right]\left(\mathrm{ClO}_{4}\right)_{2}\right\}(\mathbf{1})$ in DMSO-d $\mathrm{d}_{6}$ at room temperature.; Figure S4. Thermogravimetric analysis of complex $\left\{\left[\mathrm{Zn}(\text { bipy })_{2}\left(\mathrm{H}_{2} \mathrm{O}\right)\right]\left(\mathrm{ClO}_{4}\right)_{2}\right\}$ (1); Figure S5. IR spectrum of complex $\left\{\left[\mathrm{Zn}(\text { bipy })_{2}\left(\mathrm{H}_{2} \mathrm{O}\right)\right]\left(\mathrm{ClO}_{4}\right)_{2}\right\}$ (1); Figure S6. UV-Vis Spectrum of complex $\left\{\left[\mathrm{Zn}(\text { bipy })_{2}\left(\mathrm{H}_{2} \mathrm{O}\right)\right]\left(\mathrm{ClO}_{4}\right)_{2}\right\}$ (1); Fiure S7. Normalized response of fluorescence signal of complex $\left\{\left[\mathrm{Zn}\right.\right.$ (bipy) $\left.\left.{ }_{2}\left(\mathrm{H}_{2} \mathrm{O}\right)\right]\left(\mathrm{ClO}_{4}\right)_{2}\right\}(\mathbf{1})$ in the presence of increasing amount of acetone $(0$ to $1.05 \mathrm{mM})$ predissolved in DMSO. $\left(\lambda_{\mathrm{ex}}=295 \mathrm{~nm} ; \lambda_{\mathrm{em}}=325 \mathrm{~nm}\right)$; Figure. S8. Frontier molecular orbital of various molecules used in sensing 
studies; Figure S9. Frontier molecular orbital of the aggregate of complex $\left\{\left[\mathrm{Zn}(\text { bipy })_{2}\left(\mathrm{H}_{2} \mathrm{O}\right)\right]\left(\mathrm{ClO}_{4}\right)_{2}\right\}(\mathbf{1})$ with the various used solvents; Figure S10. Electron localization function (ELF) map of the aggregate of complex $\left\{\left[\mathrm{Zn}(\text { bipy })_{2}\left(\mathrm{H}_{2} \mathrm{O}\right)\right]\left(\mathrm{ClO}_{4}\right)_{2}\right\}(\mathbf{1})$ in different solvents; Figure S11. B3LYP/DFT optimized structures of the aggregate of complex $\left\{\left[\mathrm{Zn}(\text { bipy })_{2}\left(\mathrm{H}_{2} \mathrm{O}\right)\right]\left(\mathrm{ClO}_{4}\right)_{2}\right\}(\mathbf{1})$ in presence of various organic solvents for sensing. The $\mathrm{d} \cdots \mathrm{d}$ ' distance in angstrom represents the nearest distance between the carbon atoms of bipyridyl moiety of $\mathrm{Zn}$ (II)-complex and different solvents.

Author Contributions: All authors have read and agreed to the published version of the manuscript. Data curation, M.U.; Formal analysis, M.M. and N.A.Y.A.; Funding acquisition, M.M.; Investigation, M.M., K.A.A. and A.K.; Methodology, M.M.; Project administration, M.M. and M.A. (Musheer Ahmad); Resources, A.A.; Validation, M.M. and A.B.; Visualization, M.A. (Mohd. Afzal)

Acknowledgments: The authors are grateful to the Deanship of Scientific Research, King Saud University, for funding this work through group project number RG-1440-076. The authors also thank the Deanship of Scientific Research and RSSU at King Saud University for their technical support.

Conflicts of Interest: There are no conflicts to declare.

\section{References}

1. Han, D.; Zhao, M. Facile and simple synthesis of novel iron oxide foam and used as acetone gas sensor with sub-ppm level. J. Alloys Compd. 2020, 815, 152406. [CrossRef]

2. Baharuddin, A.A.; Ang, B.C.; Haseeb, A.S.M.A.; Wong, Y.C.; Wong, Y.H. Advances in chemiresistive sensors for acetone gas detection. Mater. Sci. Semicond. Process. 2019, 103, 104616. [CrossRef]

3. Wu, G.Y.; Chen, L.J.; Xu, L.; Zhao, X.L.; Yang, H.B. Construction of supramolecular hexagonal metallacycles via coordination-driven self-assembly: Structure, properties and application. Coord. Chem. Rev. 2018. [CrossRef]

4. Wei, P.; Yan, X.; Huang, F. Supramolecular polymers constructed by orthogonal self-assembly based on host-guest and metal-ligand interactions. Chem. Soc. Rev. 2015, 44, 815-832. [CrossRef]

5. Hosseini, M.W.; Kaes, C.; Katz, A. Bipyridine: The most widely used ligand. A review of molecules comprising at least two 2,2'-bipyridine units. Chem. Rev. 2000, 100, 3553-3590.

6. Monro, S.; Colón, K.L.; Yin, H.; Roque, J.; Konda, P.; Gujar, S.; Thummel, R.P.; Lilge, L.; Cameron, C.G.; McFarland, S.A. Transition Metal Complexes and Photodynamic Therapy from a Tumor-Centered Approach: Challenges, Opportunities, and Highlights from the Development of TLD1433. Chem. Rev. 2019, 119, 797-828. [CrossRef]

7. Qin, Q.-P.; Wang, Z.-F.; Tan, M.-X.; Huang, X.-L.; Zou, H.-H.; Zou, B.-Q.; Shi, B.-B.; Zhang, S.-H. Complexes of lanthanides (iii) with mixed 2,2'-bipyridyl and 5,7-dibromo-8-quinolinoline chelating ligands as a new class of promising anti-cancer agents. Metallomics 2019, 11, 1005-1015. [CrossRef]

8. Pohkrel, S.; Decato, D.; Rosenberg, E.; Ross, J.B.A.; Terwilliger, M. Synthesis, structure, photophysical and electrochemical properties of $\operatorname{Ru}(\mathrm{TFA})(\mathrm{CO})(\mathrm{PPh} 3) 2(\mathrm{~L})(\mathrm{L}=2$-phenylpyridine, 2-p-tolylpyridine) and $\mathrm{Ru}(\mathrm{CO})(\mathrm{PPhMe} 2) 2(\mathrm{~L})\left(\mathrm{L}^{\prime}\right)(\mathrm{L}=\mathrm{TFA}, \mathrm{H})\left(\mathrm{L}^{\prime}=\right.$ bipyridine, $\mathrm{L}^{\prime}=4,4^{\prime}$-dimethylbipyridine) relationships between ancill. J. Organomet. Chem. 2017, 849-850, 306-314. [CrossRef]

9. Solovyev, I.V.; Kondinski, A.; Monakhov, K.Y.; Koshevoy, I.O.; Grachova, E.V. Synthesis, photophysical properties and cation-binding studies of bipyridine-functionalized gold(i) complexes. Inorg. Chem. Front. 2018, 5, 160-171. [CrossRef]

10. Saleh, N.; Srebro, M.; Reynaldo, T.; Vanthuyne, N.; Toupet, L.; Chang, V.Y.; Muller, G.; Williams, J.A.G.; Roussel, C.; Autschbach, J.; et al. Enantio-Enriched CPL-active helicene-bipyridine-rhenium complexes. Chem. Commun. 2015, 51, 3754-3757. [CrossRef]

11. Toal, S.J.; Trogler, W.C. Polymer sensors for nitroaromatic explosives detection. J. Mater. Chem. 2006, 16, 2871-2883. [CrossRef]

12. Yu, X.F.; Lu, L.; Zhong, Y.R.; Luo, A.W.G.; Wang, J. Syntheses and luminescence of three lanthanide complexes constructed by flexible carboxylate ligand. Russ. J. Coord. Chem. 2017, 43, 244-251. [CrossRef]

13. Xu, H.; Liu, F.; Cui, Y.; Chen, B.; Qian, G. A luminescent nanoscale metal-organic framework for sensing of nitroaromatic explosives. Chem. Commun. 2011, 47, 3153-3155. [CrossRef] [PubMed]

14. Ahmed, Z.; Iftikhar, K. Efficient Layers of Emitting Ternary Lanthanide Complexes for Fabricating Red, Green, and Yellow OLEDs. Inorg. Chem. 2015, 54, 11209-11225. [CrossRef] [PubMed] 
15. Guo, Z.; Xu, H.; Su, S.; Cai, J.; Dang, S.; Xiang, S.; Qian, G.; Zhang, H.; O'Keeffe, M.; Chen, B. A robust near infrared luminescent ytterbium metal-organic framework for sensing of small molecules. Chem. Commun. 2011, 47, 5551-5553. [CrossRef]

16. Yi, F.Y.; Yang, W.; Sun, Z.M. Highly selective acetone fluorescent sensors based on microporous Cd(ii) metal-organic frameworks. J. Mater. Chem. 2012, 22, 23201-23209. [CrossRef]

17. Hua, J.A.; Zhao, Y.; Kang, Y.S.; Lu, Y.; Sun, W.Y. Solvent-dependent zinc(ii) coordination polymers with mixed ligands: Selective sorption and fluorescence sensing. Dalt. Trans. 2015, 44, 11524-11532. [CrossRef]

18. Li, Y.L.; Zhao, Y.; Wang, P.; Kang, Y.S.; Liu, Q.; Zhang, X.D.; Sun, W.Y. Multifunctional metal-organic frameworks with fluorescent sensing and selective adsorption properties. Inorg. Chem. 2016, 55, 11821-11830. [CrossRef]

19. Qiu, S.; Zhu, G. Molecular engineering for synthesizing novel structures of metal-organic frameworks with multifunctional properties. Coord. Chem. Rev. 2009, 253, 2891-2911. [CrossRef]

20. Zheng, X.; Zhou, L.; Huang, Y.; Wang, C.; Duan, J.; Wen, L.; Tian, Z.; Li, D. A series of metal-organic frameworks based on 5-(4-pyridyl)-isophthalic acid: Selective sorption and fluorescence sensing. J. Mater. Chem. A 2014, 2, 12413-12422. [CrossRef]

21. Harrison, W.D.; Kennedy, D.M.; Power, M.; Sheahan, R.; Hathaway, B.J. A structural profile of the bis(2,2'-bipyridyl)monochlorocopper(II) cation. Crystal structures of bis(2,2'-bipyridyl)monochlorocopper(II) perchlorate and the nitrate trihydrate. J. Chem. Soc.Dalt.Trans. 1981, 1556-1564. [CrossRef]

22. Fereday, R.J.; Hodgson, P.; Tyagi, S.; Hathaway, B.J. Crystal structure and electronic properties of bis(2,2'-bipyridyl)-nitratocopper(II) nitrate monohydrate. J. Chem. Soc.Dalt.Trans. 1981, 2070-2077. [CrossRef]

23. Wagner-Jauregg, T. Model reactions of phosphorus containing enzyme inactivators. Arzneimittelforschung 1954, 4, 527-531. [PubMed]

24. Martell, A.E.; Chaberek, S.; Courtney, R.C.; Westerback, S.; Hyytiainen, H. Hydrolytic Tendencies of Metal Chelate Compounds. I. Cu(II) Chelates1. J. Am. Chem. Soc. 1957, 79, 3036-3041. [CrossRef]

25. Sathish, V.; Ramdass, A.; Velayudham, M.; Lu, K.-L.; Thanasekaran, P.; Rajagopal, S. Development of luminescent sensors based on transition metal complexes for the detection of nitroexplosives. Dalt. Trans. 2017, 46, 16738-16769. [CrossRef] [PubMed]

26. Song, J.-B.; Wang, P.; Yan, L.; Hao, L.; Khan, M.A.; Liu, G.; Li, H. Crystal structures, red-shifted luminescence and iodide-anion recognition properties of four novel D-A type $\mathrm{Zn}$ (ii) complexes. Dalt. Trans. 2020, 49, 4358-4368. [CrossRef]

27. Germain, M.E.; Vargo, T.R.; Khalifah, P.G.; Knapp, M.J. Fluorescent Detection of Nitroaromatics and 2,3-Dimethyl-2,3-dinitrobutane (DMNB) by a Zinc Complex: (salophen)Zn. Inorg. Chem. 2007, 46, 4422-4429. [CrossRef] [PubMed]

28. Singh, G.; Kapoor, I.P.S.; Kumar, D.; Singh, U.P.; Goel, N. Preparation, X-ray crystallography and thermal decomposition of transition metal perchlorate complexes with perchlorate and 2,2'-bipyridyl ligands. Inorganica Chim. Acta 2009, 362, 4091-4098. [CrossRef]

29. Fulmer, G.R.; Miller, A.J.M.; Sherden, N.H.; Gottlieb, H.E.; Nudelman, A.; Stoltz, B.M.; Bercaw, J.E.; Goldberg, K.I. NMR Chemical Shifts of Trace Impurities: Common Laboratory Solvents, Organics, and Gases in Deuterated Solvents Relevant to the Organometallic Chemist. Organometallics 2010, 29, $2176-2179$. [CrossRef]

30. Arjmand, F.; Muddassir, M. Design and synthesis of heterobimetallic topoisomerase I and II inhibitor complexes: In vitro DNA binding, interaction with 5'-GMP and 5'-TMP and cleavage studies. J. Photochem. Photobiol. B Biol. 2010, 101, 37-46. [CrossRef]

31. Gurunatha, K.L.; Uemura, K.; Maji, T.K. Temperature- and stoichiometry-controlled dimensionality in a magnesium 4,5-imidazoledicarboxylate system with strong hydrophilic pore surfaces. Inorg. Chem. 2008, 47, 6578-6580. [CrossRef]

32. Morizzi, J.; Hobday, M.; Rix, C. Gallium (III) organophosphonate adducts with the bidentate. Inorg. Chim. Acta 2001, 320, 67-74. [CrossRef]

33. Selvakumar, B.; Rajendiran, V.; Uma Maheswari, P.; Stoeckli-Evans, H.; Palaniandavar, M. Structures, spectra, and DNA-binding properties of mixed ligand copper(II) complexes of iminodiacetic acid: The novel role of diimine co-ligands on DNA conformation and hydrolytic and oxidative double strand DNA cleavage. J. Inorg. Biochem. 2006, 100, 316-330. [CrossRef] [PubMed] 
34. Belicchi-Ferrari, M.; Bisceglie, F.; Pelosi, G.; Tarasconi, P. Heterocyclic substituted thiosemicarbazones and their $\mathrm{Cu}(\mathrm{II})$ complexes: Synthesis, characterization and studies of substituent effects on coordination and DNA binding. Polyhedron 2008, 27, 1361-1367. [CrossRef]

35. Arjmand, F.; Muddassir, M.; Khan, R.H. Chiral preference of 1-tryptophan derived metal-based antitumor agent of late 3d-metal ions (Co(II), $\mathrm{Cu}(\mathrm{II})$ and $\mathrm{Zn}(\mathrm{II})$ ) in comparison to d- and dl-tryptophan analogues: Their in vitro reactivity towards CT DNA, 5'-GMP and 5'-TMP. Eur. J. Med. Chem. 2010, 45, 3549-3557. [CrossRef] [PubMed]

36. Shustova, N.B.; Ong, T.C.; Cozzolino, A.F.; Michaelis, V.K.; Griffin, R.G.; Dincă, M. Phenyl ring dynamics in a tetraphenylethylene-bridged metal-organic framework: Implications for the mechanism of aggregation-induced emission. J. Am. Chem. Soc. 2012, 134, 15061-15070. [CrossRef]

37. Benesi, H.A.; Hildebrand, J.H. A Spectrophotometric Investigation of the Interaction of Iodine with Aromatic Hydrocarbons. J. Am. Chem. Soc. 1949, 71, 2703-2707. [CrossRef]

38. Karmaoui, M.; Leonardi, S.G.; Latino, M.; Tobaldi, D.M.; Donato, N.; Pullar, R.C.; Seabra, M.P.; Labrincha, J.A.; Neri, G. Pt-decorated In2O3 nanoparticles and their ability as a highly sensitive $(<10 \mathrm{ppb})$ acetone sensor for biomedical applications. Sens. Actuators B Chem. 2016, 230, 697-705.

39. Chen, B.; Yang, Y.; Zapata, F.; Lin, G.; Qian, G.; Lobkovsky, E.B. Luminescent open metal sites within a metal-organic framework for sensing small molecules. Adv. Mater. 2007, 19, 1693-1696. [CrossRef]

40. Yang, W.; Feng, J.; Zhang, H. Facile and rapid fabrication of nanostructured lanthanide coordination polymers as selective luminescent probes in aqueous solution. J. Mater. Chem. 2012, 22, 6819-6823. [CrossRef]

41. Li, Y.; Song, H.; Chen, Q.; Liu, K.; Zhao, F.Y.; Ruan, W.J.; Chang, Z. Two coordination polymers with enhanced ligand-centered luminescence and assembly imparted sensing ability for acetone. J. Mater. Chem. A 2014, 2, 9469-9473. [CrossRef]

(C) 2020 by the authors. Licensee MDPI, Basel, Switzerland. This article is an open access article distributed under the terms and conditions of the Creative Commons Attribution (CC BY) license (http://creativecommons.org/licenses/by/4.0/). 